\title{
Consumer Choice and Multi-Store Shopping: An Empirical Investigation
}

April 12, 2013

\author{
Sonika Singh ${ }^{1}$ \\ Lecturer, Marketing \\ University of Technology, Sydney \\ PO Box 123 Broadway \\ NSW 2007, Australia \\ Sonika.Singh@uts.edu.au
}

\author{
Brian T. Ratchford \\ Charles \& Nancy Davidson Professor of Marketing \\ Jindal School of Management \\ The University of Texas at Dallas \\ Richardson, TX 75080, USA \\ Brian.ratchford@utdallas.edu \\ Ashutosh Prasad \\ Associate Professor of Marketing \\ Jindal School of Management \\ The University of Texas at Dallas \\ Richardson, TX 75080, USA \\ aprasad@utdallas.edu
}

Word Count: 5262

\footnotetext{
${ }^{1}$ Corresponding author. The authors thank Ernan Haruvy, Andrei Strijnev and Yuanping Ying for their valuable
} advice and comments. 


\title{
Consumer Choice and Multi-Store Shopping: An Empirical Investigation
}

\begin{abstract}
We investigate the role of frequently purchased categories in multi store shopping and consumer store choice. Consumers' store choice is examined using panel data of household trips to two competing stores located in the same geographical area. A random effects bivariate probit specification incorporates own store and cross store category price and feature advertising of frequently purchased items. Stores of similar format differ in categories with significant own and cross price effects thus influencing multi-store shopping. The results indicate that for pure stockpiling categories, feature activity positively influences store choice whereas cross store category price negatively influences store choice. In categories which exhibit both stockpiling and consumption effect, we find that own store price and feature activity influence choice whereas competitor pricing does not have a significant effect.
\end{abstract}

Keywords: Store Choice; Price Competition; Random Effects Bivariate Probit 


\section{Introduction}

The goal of a retailer through its choice of category assortment, prices and feature advertising is to influence store choice. A recent 2009 consumer research report ${ }^{2}$ finds that $67 \%$ of respondents go to two or more stores to do their main grocery shopping. There is substantial competition among retailers of the similar format (Kopalle et al. 2009, González-Benito et al. 2005) and hence the benefit of attracting such shoppers is substantial. To influence store choice retailers often use loss leader promotions (Walters and Rinne 1986, Walters and Mackenzie 1988), feature advertising (Bodapati and Srinivasan 2006) or even engage in price wars. Store choice is so important that price wars between stores lead consumers to redistribute their purchases across stores and make them more sensitive to weekly prices (Van Heerde et al. 2008).

The effectiveness of retailers' marketing actions is attributed to the importance of categories in shoppers store choice decisions (Blattberg et al. 1995, Dhar et al. 2001). Briesch et al. (2010) find that "destination-ness" of categories drive consumers to visit stores of different formats. Some categories increase the shoppers' probability of choosing a particular store. Thus the consumers' behavior can vary depending on the role a category plays in his/her everyday life (Dhar et al. 2001). However, there is scant research to understand how consumers' response to marketing actions for various categories influence visit ${ }^{3}$ to more than one store of the similar format? Two stores of similar format offer similar breadth of product categories, marketing actions such as pricing, feature activity etc. We contribute to understanding of consumer store choice and retail strategy by analyzing the following research questions:

1. In a competitive setting, how do marketing actions in frequently purchased categories drive consumers to visit more than one store of the similar format in the same week?

2. Do competing stores differ in specific categories that attract consumers to the stores?

3. Which segments of consumers, based on observed or unobserved heterogeneity are most sensitive to store switching based on prices?

We employ a household level model to analyze consumer response to marketing actions in two competing grocery stores. Consumer store choice is modeled as a function of price and feature advertising in two stores located in the same geographical area. The main findings are as follows:

We find that retailer pricing in frequently purchased categories has the potential to draw consumers from the rival stores. This study finds that for pure stockpiling categories such as toilet tissue and paper towels, own store feature activity positively influences store choice whereas competing store price negatively influences store choice. In categories such as yogurt and salty snacks which exhibit both stockpiling and consumption effect, we find that own store price and feature activity influence choice whereas competitor pricing does not have a significant effect. Further, there exists some unobserved heterogeneity in consumers' response to category prices not only within a store but also across the stores. Across the stores, consumers' response to price is positively correlated for milk and soup categories.

\section{${ }^{2}$ http://plma.com/PLMA Store Brands and the Recession.pdf}

\footnotetext{
${ }^{3}$ In this study store choice and store visit are used interchangeably.
} 
The broader implication of this research for retail managers is that retailers should analyze consumers' shopping basket in conjunction with monitoring the competitors' category prices for intelligent pricing of items in consumers' basket (Kumar and Rao 2006). It would benefit retailers to identify categories which can draw consumers to a store and reduce the consumers' probability of choosing the rival store. Competing retailers of similar format should offer different categories on promotions if consumers are interested in different mixes of items in these stores.

The rest of this paper is organized as follows. A review of the literature in section 2 is followed by modeling approach in section 3. Section 4 describes the data and variable constructs. Section 5 explains the results and section 6 concludes with the summary and a prospective view of the future work.

\section{Literature and Contribution}

This study is related to literature on store choice. A summary of the literature review is presented in Table 1 below.

\section{<Insert Table 1>}

The literature on store choice finds that price, advertising and location influences choice. Prior studies look at the consumers' frequency of store visit and average size of the shopping basket as determinants of the store choice. These studies assume that consumers form an expectation of prices in all categories in a store. In the real environment, however, consumers are informed about prices in different stores especially for categories which are important constituents of their shopping basket. This information is readily available in newspaper advertisements, retailers' weekly fliers or easily obtained by talking to friends and relatives (Urbany et al. 1996). Further these studies do not model cross store effects as well as the cross category marketing actions for stores of similar format.

\section{Modeling Specification}

We analyze consumers' store choice decision for two competing grocery stores of similar format. These stores are located in the same geographical area. In general, consumers undertake weekly shopping trips and purchase some categories such as milk, snacks, tissues, cereals etc. more frequently than other categories. Consumers are routinely targeted by competing stores with price information of frequently purchased categories using fliers and advertisements. Simester (1997) finds that in a competitive setting, price advertising of frequently purchased categories serves as a commitment device for multiproduct retailers to influence consumers to purchase all items in one store.

However, it may not necessarily be the case that consumers buy all items in one store. Consumer motivations to make purchases in categories differ depending on the type of category i.e. staple (high frequency-high penetration) or non-staple category. The retailers' success in generating demand would depend on the role that a category plays in a consumer's portfolio (Dhar et al. 2001). The competing stores may develop expertise in particular categories (Dhar et al. 2001) and pricing of these categories would influence consumers' choice of rival store. Therefore, we expect that consumers who shop at competing stores of the similar format would be attracted to the stores for specific categories. Therefore, 
H1: Stores of similar format differ in categories where price impacts the choice of competing store.

Prior findings suggest that feature activity in frequently purchased categories that can be stockpiled may influence store choice. The promotional elasticities are higher for categories such as bathroom tissue, paper towels, and yogurt (Narasimhan et al. 1996; Bell et al. 2002). These categories exhibit higher consumer propensity to stockpile. Hence the categories that can be stockpiled readily should react strongly to promotion. Therefore we expect that:

$\mathrm{H} 2$ : Feature activity in categories that can be stockpiled negatively influences competitor store choice.

The model specification is explained next. We follow the prior literature for model specification (Van Heerde et al. 2008, Chib et al 2002, Manchanda, Ansari and Gupta 1999) and incorporate the cross-store effects, store co-incidence and unobserved heterogeneity allowing for the possibility of a household to visit both the stores in a given week. Since the focus of this study is to understand the role of categories on store choice in a competitive setting; we do not model consumers' purchase incidence.

Let the households' decision to shop in store $\mathrm{s}$, week $\mathrm{t}$ be represented by $\mathrm{y}_{\mathrm{ht}}$. $\mathrm{y}_{\mathrm{ht}}$ is a vector of binary dependent variables as shown:

$$
\mathrm{y}_{\mathrm{ht}}=\left(\mathrm{y}_{\mathrm{htA}}, \mathrm{y}_{\mathrm{htB}}\right)^{\prime} \mathrm{C}\{(0,0),(0,1),(1,0),(1,1)\}
$$

$\mathrm{h}=1, \ldots, \mathrm{H} ; \mathrm{t}=1, \ldots, \mathrm{T} ; \mathrm{s} \in\{\mathrm{A}, \mathrm{B}\}$ where subscripts $\mathrm{h}, \mathrm{t}$, s refer to household, week and store respectively. The household's underlying latent utility for each of the two stores can be expressed as:

$$
\begin{aligned}
& z_{h A t}=\beta_{A}^{\prime} X_{h A t}+\varepsilon_{h A t} \\
& z_{h B t}=\beta_{B}^{\prime} X_{h B t}+\varepsilon_{h B t}
\end{aligned}
$$

$X_{h A t}{ }^{\prime}$ is $\mathrm{k}_{1}$ dimensional vector of variables that comprise of own store and cross store effects for store A. This includes the price, feature and display information of 10 categories under consideration in store A and B respectively. Similarly, $X_{h B t}{ }^{\prime}$ is $\mathrm{k}_{2}$ dimensional vector of marketing activities in store $\mathrm{B}$ as well as competing store $\mathrm{A} . \beta_{A}^{\prime}$ and $\beta_{B}^{\prime}$ represent the change in choice utility of store $A$ and $B$ due to own store marketing actions as well marketing actions of the competing store. The observed trip to a store s $E\{A, B\}$ and the latent utility of the household are linked as follows:

$$
y_{h s t}= \begin{cases}1, & \text { if } z_{h s t}>0 \\ 0, & \text { if } z_{h s t} \leq 0\end{cases}
$$

The utility equations for household $\mathrm{h}$ in week $\mathrm{t}$ for the two stores can be compactly written as:

$$
z_{h t}=\beta^{\prime} X_{h t}+\varepsilon_{h t}
$$

where $z_{\mathrm{ht}}$ is s dimensional vector. $X_{\mathrm{ht}}$ is a matrix of variables influencing the utility of trip to store $\mathrm{A}$ and $\mathrm{B} . \beta=\left\{\beta_{A}, \beta_{B}\right\}^{\prime}$ is a vector of coefficients of the causal variables. $\varepsilon_{\mathrm{ht}}=\left(\varepsilon_{\mathrm{htA}}, \varepsilon_{\mathrm{htB}}\right)^{\prime}$ represents the unobserved random factors that may impact store choice. Since there may be common unobserved factors across the two stores, therefore, $\varepsilon_{\mathrm{ht}}$ is assumed to have bivariate normal structure i.e. $\varepsilon_{\mathrm{ht}} \sim \mathrm{MVN}(0, \Sigma) . \Sigma$ is a $2 \times 2$ variance-covariance matrix. We expect the households to differ in their preference for the two stores as well as response to prices in the two 
stores. Therefore, we allow the coefficients of intercept terms and prices in six frequently purchased categories to vary across individuals.

The above specification results in a bivariate probit model (Chib and Greenberg 1998). Given the two stores and T=52 weeks of observations for each household h, the households' likelihood function of store choice is given by:

$$
\begin{aligned}
& \operatorname{Pr}\left(Y_{h}=y_{h} \mid \beta, \delta_{h}, \rho\right) \equiv \operatorname{pr}\left(y_{h} \mid \beta, \delta_{h}, \rho\right) \\
& \propto \int\left[\prod_{t=1}^{T} \int_{B_{h t s}}\left[\phi_{s}\left(Z_{h t} \mid W_{h} \delta_{h}+X_{h t} \beta, \Sigma\right) d Z_{h t}\right] \phi\left(\delta_{h} \mid 0, D\right) d Z_{h}\right]
\end{aligned}
$$

where $\mathrm{B}_{\mathrm{hts}}$ is the interval $(0, \infty)$ if $\mathrm{y}_{\mathrm{hts}}=1$ and interval $(-\infty, 0)$ if $\mathrm{y}_{\mathrm{hts}}=0 . \delta^{\prime}{ }_{h}$ represents the vector of household specific random effects and $\rho$ captures the store co-incidence. We use data augmentation framework (Albert and Chib 1993, Chib and Greenberg 1995, 1998) to estimate the model parameters. Data augmentation is based on sampling by Markov Chain Monte Carlo technique (Gelfand and Smith 1990) using conditional distributions.

\section{Data Description}

The model is estimated using IRI scanner panel data from Massachusetts area. Data consists of households tracked over a period of 52 weeks from December 2004 to December, 2005. There are 14 stores of various formats in this area. Of these, 7 are grocery stores. Two grocery stores of competing chains, henceforth referred to as store A and store B are selected for the analysis. These stores account for more than fifty percent sales in that area. The data has household level information on price, feature and display for 30 categories sold in each of the two stores. Of all the categories, 10 top selling categories are selected for analysis at the individual household level. These are frequently purchased categories that can be stockpiled (toilet tissues, paper towels, salted snacks, soft drinks, and yogurt) as well as those that cannot be stockpiled (frozen dinner entrée, cold cereal, soup, milk and spaghetti). This classification of categories is based on prior studies (Bell et al. 2002, Narasimhan et al.1996).

The data consists of households that have purchased across seven grocery stores in the area. Of these households, 100 households made $60 \%$ or more of total trips to the two selected stores. Out of these households, 74 households were randomly selected for the purpose of analysis. The data set for empirical analysis consists of information about consumers' store choice (dummy variable) which is the dependent variable in this analysis.

The independent variables are price, display, feature and inventory level of the household. Category price is household specific and calculated as the weighted average of the price of all the SKU's purchased by the consumer in week $t$ in store $s=\{A, B\}$ (Bucklin and Lattin 1992). The weekly category feature and display variables are also calculated for every individual household in a similar manner as the household specific price. Therefore these variables take a value between 0 and 1 . Besides the marketing activity we also control for consumer demographics such as age, income, marital status, education, holiday and household inventory. Table 2 gives the descriptive statistics of the marketing variables for each of the 10 categories.

$<$ Insert Table 2> 
Table 2 shows that category prices in the two stores are similar for most categories. The number of visits to store A is 972 and 1047 in store B. There are 713 trips where consumers have visited both the store and 1116 trips where none of the stores have been visited. The results of model estimation are explained in the next section.

\section{Results}

Results from Table 3 indicate that own store category price as well as competitor category price impact store choice. The results for own store category price effects indicate that price increase in cereals $(\beta=-0.82)$, frozen dinner entree $(\beta=-0.77)$ and yogurt $(\beta=-1.17)$ category negatively impact choice of store A. For store $B$, price increase of milk $(\beta=-0.71)$ and salty snacks $(\beta=-0.66)$ negatively influences store choice.

The cross store category effects indicate that visit to store $A$ is sensitive to price increase in store $\mathrm{B}$ for frozen dinner entrée $(\beta=0.62)$, spaghetti $(\beta=0.56)$, paper towels $(\beta=1.09)$ and toilet tissues $(\beta=0.51)$ categories. On the other hand visit to store $B$ is sensitive to price increase in store $A$ for soup $(\beta=0.41)$, milk $(\beta=0.81)$ and toilet tissues $(\beta=0.81)$ categories. A price increase in toilet tissue category in either of the stores results in consumers choosing the competing store. These results support hypothesis H1suggesting that category pricing has the power to draw consumers from the competing store.

Feature activity also influences store choice. For store A, all categories except salty snacks, when featured influence store choice. Similarly for store B, all categories except milk, when featured influence store choice.

The cross store feature activity indicates that salty snacks and yogurt categories when featured by store B negatively impact consumers' choice of store $A(\beta=-0.35,-0.36$ for salty snacks and yogurt respectively). Milk and spaghetti categories featured by store $A$, have a negative influence choice of store $B(\beta=-0.41,-0.53$ for milk and spaghetti respectively). Salty snacks category is significant but with a wrong sign of the coefficient. Though cross store feature activity is significant, there is weak support for the hypothesis H2 that competitors' feature activity in stockpiling categories influences store choice.

An interesting observation is that for pure stockpiling categories such as toilet tissue and paper towels, own store feature activity and cross store category price influence consumer choice. For instance, in store A, paper towels and toilet tissue categories when featured positively influence store choice. However, competitor store price in these categories negatively influences store choice. A similar effect is observed for toilet tissues category in store B. For categories which exhibit both stockpiling and consumption effect (such as Yogurt in store A, salty snacks in store B) we find that own store price and feature activity influence choice. These findings suggest that identifying categories where choice is sensitive to own store price and feature activity has implications on retailers' marketing actions. The results from Table 4 indicate that consumers differ in their sensitivity to prices within and across the two stores for some categories. Across the stores there is positive correlation between price of carbonated beverage in store A and soup in store B. Price of frozen dinner entrée in store A is positively related to price of soup and milk in store B. These findings indicate that there exists some unobserved heterogeneity in consumers' response to category prices not only within a store but also across the stores. These results suggest the existence of latent segments among consumers who shop in more than one store for different categories. 
Besides the above results, inventory level of the household also influences store choice. A reduction in the inventory for cereals, and paper towel categories positively influences consumers to choose store A. Low levels of household inventory in salty snacks and yogurt category positively influence visit to store B. However, we obtain wrong sign for impact of inventory of soup category in store A and spaghetti and toilet tissues for store B. A possible explanation is as follows. These are frequently consumed categories with a fairly constant rate of consumption as compared to other categories. Empirical evidence in prior literature indicates that consumers tend to stockpile in categories such as toilet tissues (Bell et al. 2002, Hong et al. 2002).Therefore, it is possible that whenever these categories are featured or on promotion, consumers visit the stores intending to stockpile these categories.

\section{Conclusion}

The objective of this study is to understand consumers' response to shopping at more than one store of similar format in a given week. To summarize; the results indicate that two stores of similar format differ in categories with significant own and cross price effects. The findings of this analysis suggest that consumers may be interested in different mixes of items in competing stores (Kopalle et al. 2009) and therefore visit both the stores. Multi store shoppers use pricing information of competing stores before visiting stores. They may access this information through feature advertising (Urbany et al. 2000, Bodapati and Srinivasan 2006), consulting friends (Urbany et al. 1996), searching online for price information (Degeratu and Rangaswamy 2000) or through their own experience of visiting the competing and buying in these categories. The findings of this study imply that analyzing consumers' shopping basket in conjunction with monitoring the competitors' category prices would lead to intelligent category pricing (Kumar and Rao 2006).

Future research could address some of the limitations of this study. We assume that items in the consumers' shopping basket do not vary over time which may not necessarily be the case. Future work can analyze multiple stores and explore how store trips and category purchases vary for competing stores of the similar and different formats. This may provide additional insights about consumer motivation to shop multiple stores of similar and dissimilar formats. 


\section{References}

Albert, J., \& Chib,S. (1993). Bayesian Analysis of Binary and Polychotomous Response Data. Journal of the American Statistical Association, 88, 669-679.

Bell, D. R., G.Iyer, V. Padmanabhan. 2002. Price Competition under Stockpiling and Flexible Consumption. Journal of Marketing Research. 39,3: 292-303.

Bell, D.R., J.M. Lattin. 1998. Shopping Behavior and Consumer Preference for Store Price Format: Why "Large Basket" Shoppers Prefer EDLP; Marketing Science, 17.

Blattberg, R.C., S.A. Neslin.1995. Sales Promotion: Concepts, Methods, and Strategies, Englewood Cliffs, N.J.: Prentice Hall.

Bodapati, A. V., V. Srinivasan.2006. The Impact of Out-of-Store Advertising on Store Sales. Working Paper, University of California at Los Angeles.

Briesch, R.A., W.R. Dillon, E.J, Fox. 2010. Destination Categories and Store Choice. Working Paper.

Bucklin, R. E., J. M. Lattin. 1992. A model of product category competition among grocery retailers. Journal of Retailing, 68, 3: 271-293.

Chib, S., E.Greenberg. 1998. Analysis of multivariate probit models. Biometrika, 85,_2:347-361.

Chib, S.,E. Greenberg. 1995. Understanding the Metropolis-Hastings Algorithm. The American Statistician, 49, 327-335.

Chib, S., P.B. Seetharaman, A. Strijnev. 2002. Analysis of multi-category purchase incidence decisions using IRI market basket data, Econometric Models in Marketing. Advances in Econometrics, A. Montgomery and P.H Franses (Eds), Elsevier Science, 16. Print.

Dhar, S. K., S.J. Hoch, and N. Kumar. 2001. Effective category management depends on the role of the category. Journal of Retailing 77, 2:165-184.

Degeratu, A. M., A. Rangaswamy, J. Wu. 2000.Consumer Choice Behavior in Online and Traditional Supermarkets: The Effects of Brand Name, Price, and Other Search Attributes. International Journal of Research in Marketing, 17, 1:55-78.

Gelfand, A., A.Smith.1990. Sampling-based Approaches to Calculating Marginal Densities. Journal of the American Statistical Society, 85, 398-409.

González-Benito, Óscar, P.A. Munoz-Gallego, P.K. Kopalle. 2005.Asymmetric Competition in Retail Store Formats: Evaluating Inter and Intra-format Spatial Effects. Journal of Retailing,81, 1:75-9. 
Hong, P., R. P. McAfee, A.Nayyar. 2002. Equlibrium Price Despersion with Consumer Inventories. Journal of Economic Theory.105,2: 503-517.

Kopalle, P., D. Biswas, P. K. Chintagunta, J Fan, K. Pauwels, B. T. Ratchford, J. A. Sills. 2009. Retailer Pricing and Competitive Effects, Journal of Retailing. 85,1:56-70.

Kumar, V., R.P. Leone (1988). Measuring the Effect of Retail Store Promotions on Brand and Store Substitution. Journal of Marketing Research. 25, 2:178:185.

Kumar, N., R. C. Rao.2006. Using Basket Composition Data for Intelligent Supermarket Pricing. Marketing Science, 25, 2:188-199.

Manchanda, P., A. Ansari, S.Gupta 1999. The" shopping basket": A model for multicategory purchase incidence decisions. Marketing Science, 18, 2:95-114.

Narasimhan, C., S. A. Neslin, S.K. Sen. 1996. Promotional Elasticities and Category Characteristics. Journal of Marketing, 60, 2:17-30.

Simester, D.1997. Optimal Promotion Strategies: A Demand-Sided Characterization. Management Science,43,2: 251-256.

Urbany, J.E., P. R. Dickson, A. G. Sawyer. 2000. Insights into Cross- and Within-Store Price Search: Retailer Estimates vs. Consumer Self-Reports. Journal of Retailing,76, 2:.243258.

Urbany, J.E., P. R. Dickson,R. Kalapurakal. 1996. Price search in the retail grocery market. Journal of Marketing,60,2:91-104.

Van Heerde, H.J., E. Gijsbrechts, K. Pauwels.2008. Winners and Losers in a Major Price War. Journal of Marketing Research, 45,5:499-518.

Walters, R.G., S.B. MacKenzie.1988. A structural Equations Analysis of the impact of Price Promotions on Store performance. Journal of Marketing Research, 25, 51-63.

Walters, R.G., H. Rinne.1986. An empirical investigation into the impact of price promotions on Retail Store Performance, Journal of Retailing, 62.

Walters, R.G. 1991. Assessing the Impact of Retail Price Promotions on Product Substitution, ComplementaryPurchase, and Interstore Sales Displacement, Journal of Marketing, 55, 17-28. 
Table 1: Literature Review

\begin{tabular}{|c|c|c|c|}
\hline Literature & $\begin{array}{l}\text { Marketing Mix Variable } \\
\text { of Interest }\end{array}$ & $\begin{array}{l}\text { Dependent } \\
\text { Variable }\end{array}$ & $\begin{array}{l}\text { Main } \\
\text { Findings }\end{array}$ \\
\hline $\begin{array}{l}\text { Kumar \& Leone } \\
\text { (1988) }\end{array}$ & Brand Promotions & Store sales & $\begin{array}{l}\text { Price promotion, } \\
\text { feature and display } \\
\text { produce store } \\
\text { substitution. }\end{array}$ \\
\hline Walters 1991 & Retail price promotion & $\begin{array}{l}\text { Store sales of } \\
\text { competing } \\
\text { retailers }\end{array}$ & $\begin{array}{l}\text { Promotions of } \\
\text { products in one } \\
\text { store significantly } \\
\text { decreased sales of } \\
\text { substitutes and } \\
\text { complements in a } \\
\text { competing store. }\end{array}$ \\
\hline $\begin{array}{l}\text { Bodapati \& Srinivasan } \\
(2006)\end{array}$ & Feature advertising & Store choice & $\begin{array}{l}\text { Feature } \\
\text { advertising } \\
\text { impacts price } \\
\text { expectations for } \\
\text { advertised and } \\
\text { unadvertised } \\
\text { items, impacting } \\
\text { store choice and } \\
\text { traffic. }\end{array}$ \\
\hline Bell \& Lattin (1998) & $\begin{array}{l}\text { Expected basket } \\
\text { attractiveness }\end{array}$ & Store choice & $\begin{array}{l}\text { Consumers whose } \\
\text { trips tend to be } \\
\text { infrequent and } \\
\text { large see higher } \\
\text { expected basket } \\
\text { attractiveness in } \\
\text { EDLP stores than } \\
\text { in HILO stores. }\end{array}$ \\
\hline
\end{tabular}


Table 1 contd: Literature Review

\begin{tabular}{|c|c|c|c|}
\hline Literature & $\begin{array}{l}\text { Marketing Mix Variable } \\
\text { of Interest }\end{array}$ & $\begin{array}{l}\text { Dependent } \\
\text { Variable }\end{array}$ & $\begin{array}{l}\text { Main } \\
\text { Findings }\end{array}$ \\
\hline $\begin{array}{l}\text { Van Heerde et al. } \\
(2008)\end{array}$ & Price wars & Store Choice & $\begin{array}{l}\text { Price wars lead to } \\
\text { more shopping } \\
\text { around and } \\
\text { increased spending. } \\
\text { However spending } \\
\text { per visit ultimately } \\
\text { dropped because } \\
\text { consumers } \\
\text { redistributed their } \\
\text { purchases across } \\
\text { stores. }\end{array}$ \\
\hline Briesch et al. (2010) & Category destination-ness & Store Choice & $\begin{array}{l}\text { Destination } \\
\text { categories are most } \\
\text { influential in store } \\
\text { choice decisions } \\
\text { (i.e. high leverage). } \\
\text { The high leverage } \\
\text { categories tend to be } \\
\text { purchased } \\
\text { frequently, consume } \\
\text { a high share of } \\
\text { household spending } \\
\text { and be } \\
\text { fresh/refrigerated or } \\
\text { frozen categories. }\end{array}$ \\
\hline Present Research & $\begin{array}{l}\text { Own and Cross store price } \\
\text { and feature advertising of } \\
\text { frequently purchased } \\
\text { categories }\end{array}$ & Store choice & $\begin{array}{l}\text { Identify power } \\
\text { categories whose } \\
\text { prices significantly } \\
\text { affect the choice of } \\
\text { the competing } \\
\text { stores. Competing } \\
\text { stores have different } \\
\text { power categories. }\end{array}$ \\
\hline
\end{tabular}




\section{Table 2: Data Description}

Number of households $=74$

Number of weeks $=52$

Store Trips

Number of Observed Store Trips

\begin{tabular}{ccccc}
\hline & & & & Total \\
Store A & Store B & Both the stores & None of the stores & Observations \\
972 & 1047 & 713 & 1116 & $74 \times 52=3848$ \\
\hline
\end{tabular}

\begin{tabular}{|c|c|c|c|c|c|c|}
\hline & \multicolumn{3}{|c|}{ STORE A } & \multicolumn{3}{|c|}{ STORE B } \\
\hline When store trips occur & $\begin{array}{l}\text { Price } \\
(\$ / \text { unit })\end{array}$ & Feature & Display & $\begin{array}{l}\text { Price } \\
(\$ / \text { unit })\end{array}$ & Feature & Display \\
\hline Carbonated Beverage & 0.024951 & 0.093253 & 0.048203 & 0.027928 & 0.049937 & 0.0624 \\
\hline Cold cereal & 3.741628 & 0.030309 & 0.020878 & 3.686399 & 0.031559 & 0.024686 \\
\hline Soup & 2.016194 & 0.023433 & 0.013998 & 1.590983 & 0.017722 & 0.01446 \\
\hline Milk & 0.615469 & 0.016685 & 0.00026 & 0.586468 & 0.031279 & 0.003217 \\
\hline Frozen Dinner Entrée & 4.079818 & 0.010942 & 0.001741 & 4.512423 & 0.013179 & 0.005237 \\
\hline Paper Towel & 1.881339 & 0.007119 & 0.007926 & 1.956175 & 0.012487 & 0.010796 \\
\hline Spaghetti & 1.567648 & 0.015173 & 0.007617 & 1.341972 & 0.02079 & 0.014557 \\
\hline Salty Snacks & 4.140392 & 0.002631 & 0.03696 & 3.861494 & 0.056665 & 0.058003 \\
\hline Toilet Tissue & 0.654706 & 0.014308 & 0.012383 & 0.632485 & 0.016545 & 0.011446 \\
\hline Yogurt & 1.981436 & 0.021142 & 0 & 1.988248 & 0.031992 & 0.00705 \\
\hline $\begin{array}{l}\text { When store trips do not take } \\
\text { place }\end{array}$ & $\begin{array}{l}\text { Price } \\
(\$ / \text { unit })\end{array}$ & Feature & Display & $\begin{array}{l}\text { Price } \\
(\$ / \text { unit })\end{array}$ & Feature & Display \\
\hline Carbonated Beverage & 0.025474 & 0.040845 & 0.03159 & 0.027928 & 0.04995 & 0.062416 \\
\hline Cold cereal & 3.741629 & 0.030317 & 0.020884 & 3.686517 & 0.031534 & 0.024666 \\
\hline Soup & 2.016355 & 0.023439 & 0.014001 & 1.591089 & 0.017727 & 0.014464 \\
\hline Milk & 0.615832 & 0.016672 & 0.00026 & 0.586847 & 0.031255 & 0.003214 \\
\hline Frozen Dinner Entrée & 4.080616 & 0.010934 & 0.001739 & 4.512776 & 0.013168 & 0.005233 \\
\hline Paper Towel & 1.881252 & 0.007113 & 0.00792 & 1.956395 & 0.012477 & 0.010528 \\
\hline Spaghetti & 1.56697 & 0.015161 & 0.007611 & 1.341687 & 0.020774 & 0.014546 \\
\hline Salty Snacks & 4.144944 & 0.002629 & 0.036931 & 3.861341 & 0.05662 & 0.057958 \\
\hline Toilet Tissue & 0.654484 & 0.014297 & 0.012373 & 0.632604 & 0.016532 & 0.011437 \\
\hline Yogurt & 1.981551 & 0.021126 & 0 & 1.988147 & 0.031967 & 0.007044 \\
\hline
\end{tabular}


Table 3: Results of Bivariate Probit estimation

\begin{tabular}{|c|c|c|c|c|c|c|c|c|c|}
\hline \multirow[b]{3}{*}{ Own store price } & \multirow[b]{3}{*}{ Intercept } & \multicolumn{4}{|c|}{ STORE A } & \multicolumn{4}{|c|}{ STORE B } \\
\hline & & \multirow{2}{*}{$\begin{array}{l}\text { est. } \\
0.70\end{array}$} & \multirow{2}{*}{$\frac{\text { std }}{1.36}$} & \multicolumn{2}{|c|}{ 95\% HDPI } & \multirow{2}{*}{$\begin{array}{l}\text { est. } \\
0.34\end{array}$} & \multirow{2}{*}{$\begin{array}{l}\text { std } \\
1.42\end{array}$} & \multicolumn{2}{|c|}{ 95\% HDPI } \\
\hline & & & & -1.99 & 3.37 & & & -2.36 & 3.14 \\
\hline & Carbonated Beverage & 0.08 & 0.15 & -0.22 & 0.37 & -0.11 & 0.22 & -0.53 & 0.32 \\
\hline & Cold cereal & -0.82 & 0.27 & -1.36 & -0.29 & -0.17 & 0.33 & -0.83 & 0.49 \\
\hline & Soup & 0.27 & 0.11 & 0.04 & 0.49 & -0.22 & 0.23 & -0.68 & 0.25 \\
\hline & Milk & -0.33 & 0.34 & -1.00 & 0.32 & $-0.71 *$ & 0.41 & -1.40 & -0.19 \\
\hline & Frozen Dinner Entrée & -0.77 & 0.19 & -1.14 & -0.38 & 0.88 & 0.28 & 0.31 & 1.42 \\
\hline & Paper Towel & 0.36 & 0.22 & -0.07 & 0.80 & -0.09 & 0.33 & -0.75 & 0.55 \\
\hline & Spaghetti & -0.13 & 0.15 & -0.44 & 0.15 & 0.15 & 0.19 & -0.23 & 0.53 \\
\hline & Salty Snacks & -0.06 & 0.15 & -0.36 & 0.24 & -0.66 & 0.20 & -1.08 & -0.29 \\
\hline & Toilet Tissue & 0.32 & 0.27 & -0.22 & 0.85 & 0.23 & 0.28 & -0.32 & 0.80 \\
\hline & Yogurt & -1.17 & 0.38 & -1.97 & -0.47 & 0.39 & 0.34 & -0.31 & 1.05 \\
\hline \multicolumn{10}{|c|}{ Competitor store price } \\
\hline & Carbonated Beverage & 0.18 & 0.15 & -0.11 & 0.47 & -0.04 & 0.13 & -0.29 & 0.21 \\
\hline & Cold cereal & 0.26 & 0.27 & -0.27 & 0.78 & -0.19 & 0.23 & -0.62 & 0.27 \\
\hline & Soup & 0.06 & 0.20 & -0.33 & 0.46 & 0.41 & 0.11 & 0.20 & 0.63 \\
\hline & Milk & 0.45 & 0.29 & -0.11 & 1.01 & 0.81 & 0.28 & 0.27 & 1.34 \\
\hline & Frozen Dinner Entrée & 0.62 & 0.26 & 0.15 & 1.15 & 0.19 & 0.21 & -0.22 & 0.61 \\
\hline & Paper Towel & 1.09 & 0.29 & 0.52 & 1.66 & -0.11 & 0.21 & -0.52 & 0.30 \\
\hline & Spaghetti & 0.56 & 0.19 & 0.20 & 0.93 & -0.09 & 0.15 & -0.38 & 0.20 \\
\hline & Salty Snacks & -0.67 & 0.13 & -0.93 & -0.41 & -0.26 & 0.13 & -0.52 & -0.01 \\
\hline & Toilet Tissue & 0.51 & 0.26 & 0.01 & 1.04 & 0.81 & 0.27 & 0.28 & 1.34 \\
\hline & Yogurt & -0.13 & 0.26 & -0.66 & 0.38 & 0.02 & 0.27 & -0.51 & 0.56 \\
\hline
\end{tabular}

Note: The numbers in bold are significant at $95 \%$ confidence level 
Table 3 contd: Results of Bivariate Probit estimation

\begin{tabular}{|c|c|c|c|c|c|c|c|c|c|}
\hline \multirow{3}{*}{ Own Store Feature } & \multirow[b]{3}{*}{ Carbonated Beverage } & \multicolumn{4}{|c|}{ STORE A } & \multicolumn{4}{|c|}{ STORE B } \\
\hline & & est. & \multirow{2}{*}{$\frac{\text { std }}{0.66}$} & \multicolumn{2}{|c|}{ 95\% HDPI } & \multirow{2}{*}{$\frac{\text { est. }}{\mathbf{0 . 5 0}}$} & \multirow{2}{*}{$\frac{\text { std }}{0.14}$} & \multicolumn{2}{|c|}{ 95\% HDPI } \\
\hline & & 1.92 & & 0.87 & 3.44 & & & 0.23 & 0.77 \\
\hline & Cold cereal & 2.64 & 0.79 & 1.17 & 4.22 & 3.12 & 1.25 & 0.96 & 5.87 \\
\hline & Soup & 3.09 & 1.44 & 0.64 & 5.62 & 4.05 & 2.17 & 0.86 & 7.57 \\
\hline & Milk & 2.07 & 0.63 & 0.88 & 3.39 & 1.01 & 5.62 & -9.90 & 12.07 \\
\hline & Frozen Dinner Entrée & 2.97 & 1.06 & 1.07 & 5.35 & 5.49 & 2.40 & 1.07 & 8.49 \\
\hline & Paper Towel & 3.55 & 2.22 & 0.50 & 9.03 & 2.26 & 1.45 & 0.09 & 4.86 \\
\hline & Spaghetti & 2.12 & 1.06 & 0.58 & 4.35 & 1.51 & 0.78 & 0.47 & 3.26 \\
\hline & Salty Snacks & 4.67 & 3.87 & -0.81 & 13.26 & 1.96 & 1.14 & 0.56 & 4.45 \\
\hline & Toilet Tissue & 2.47 & 1.65 & 0.42 & 5.71 & 2.37 & 1.72 & 0.08 & 5.59 \\
\hline & Yogurt & 1.94 & 0.63 & 0.71 & 3.63 & 1.75 & 0.74 & 0.75 & 3.31 \\
\hline \multirow[t]{10}{*}{ Competitor Store feature } & Carbonated Beverage & 0.03 & 0.18 & -0.31 & 0.38 & -0.11 & 0.17 & -0.45 & 0.22 \\
\hline & Cold cereal & 0.10 & 0.19 & -0.29 & 0.47 & 0.00 & 0.19 & -0.39 & 0.37 \\
\hline & Soup & -0.23 & 0.26 & -0.75 & 0.26 & -0.02 & 0.19 & -0.40 & 0.36 \\
\hline & Milk & -0.08 & 22.58 & -43.96 & 43.55 & $-0.41 *$ & 0.27 & -0.86 & -0.07 \\
\hline & Frozen Dinner Entrée & -0.31 & 0.31 & -0.93 & 0.28 & 0.17 & 0.28 & -0.38 & 0.72 \\
\hline & Paper Towel & 0.13 & 0.29 & -0.45 & 0.68 & 0.12 & 0.33 & -0.52 & 0.77 \\
\hline & Spaghetti & 0.15 & 0.22 & -0.29 & 0.58 & -0.53 & 0.27 & -1.09 & -0.01 \\
\hline & Salty Snacks & -0.35 & 0.14 & -0.62 & -0.08 & 17.50 & 8.70 & 3.50 & 34.20 \\
\hline & Toilet Tissue & 0.40 & 0.23 & -0.04 & 0.86 & 0.19 & 0.26 & -0.33 & 0.69 \\
\hline & Yogurt & $-0.36 *$ & 0.20 & -0.70 & -0.11 & -0.20 & 0.22 & -0.64 & 0.23 \\
\hline \multirow[t]{10}{*}{ Own Store Display } & Carbonated Beverage & 2.61 & 0.70 & 1.28 & 3.95 & 2.06 & 0.71 & 0.90 & 3.42 \\
\hline & Cold cereal & 1.58 & 0.69 & 0.56 & 3.00 & 2.38 & 0.98 & 1.01 & 4.92 \\
\hline & Soup & 2.92 & 1.67 & 0.33 & 6.15 & 2.68 & 1.20 & 0.73 & 5.19 \\
\hline & Milk & 5.14 & 4.46 & -1.30 & 14.88 & 5.14 & 2.32 & 1.19 & 9.17 \\
\hline & Frozen Dinner Entrée & 6.73 & 5.39 & -2.66 & 15.47 & 2.30 & 1.23 & 0.38 & 4.89 \\
\hline & Paper Towel & 3.50 & 2.49 & 0.48 & 9.69 & 3.42 & 1.63 & 0.34 & 6.78 \\
\hline & Spaghetti & 1.39 & 0.88 & 0.12 & 3.42 & 1.61 & 1.02 & 0.27 & 3.92 \\
\hline & Salty Snacks & 3.21 & 0.60 & 2.31 & 4.72 & 2.29 & 0.67 & 1.10 & 3.57 \\
\hline & Toilet Tissue & 3.36 & 2.30 & 0.26 & 7.19 & 2.07 & 1.65 & 0.00 & 5.81 \\
\hline & $\begin{array}{l}\text { Correlation } \\
\text { coefficient }\end{array}$ & -0.03 & 0.04 & -0.10 & 0.05 & & & & \\
\hline
\end{tabular}

Note: The numbers in bold are significant at $95 \%$ confidence level. $*$ is significant at $90 \%$ confidence level. 
Table 3 contd: Results of Bivariate Probit estimation

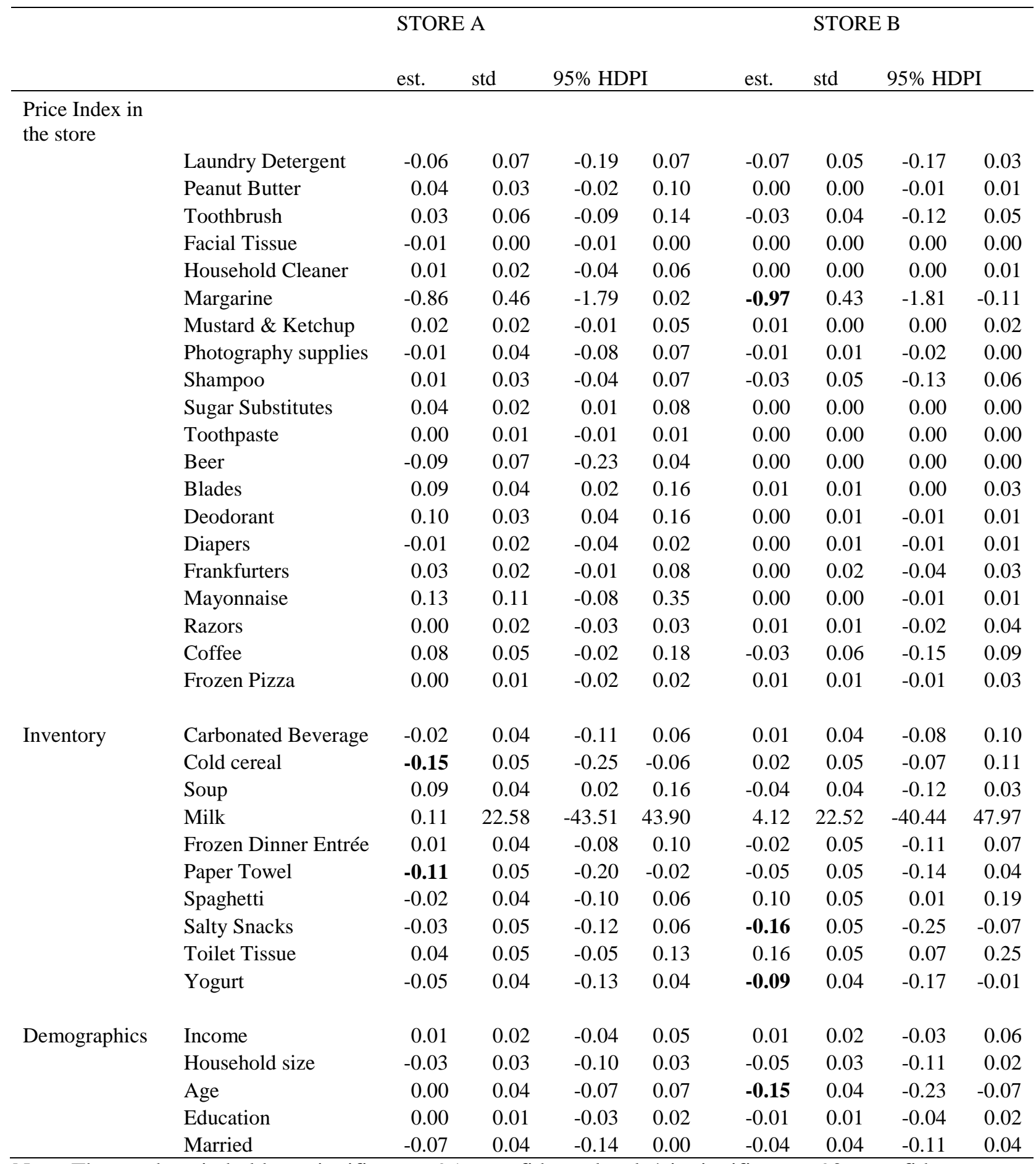

Note: The numbers in bold are significant at $95 \%$ confidence level. $*$ is significant at $90 \%$ confidence level. 
Table 4: Unobserved Heterogeneity Matrix

\begin{tabular}{|c|c|c|c|c|c|c|c|c|c|c|c|c|c|c|}
\hline & $\begin{array}{l}\text { Intercept } \\
\text { A }\end{array}$ & $\begin{array}{l}\text { CB- } \\
\text { A }\end{array}$ & CC-A & $\begin{array}{l}\text { SOUP- } \\
\text { A }\end{array}$ & $\begin{array}{l}\text { MILK- } \\
\text { A }\end{array}$ & $\begin{array}{l}\text { FDE- } \\
\mathrm{A}\end{array}$ & PT-A & $\begin{array}{l}\text { Intercept } \\
\mathrm{B}\end{array}$ & $\begin{array}{l}\text { CB- } \\
\mathrm{B} \\
\end{array}$ & $\begin{array}{l}\mathrm{CC}- \\
\mathrm{B} \\
\end{array}$ & $\begin{array}{l}\text { SOUP- } \\
\mathrm{B}\end{array}$ & $\begin{array}{l}\text { MILK- } \\
\text { B }\end{array}$ & $\begin{array}{l}\text { FDE- } \\
\mathrm{B}\end{array}$ & $\begin{array}{l}\text { PT- } \\
\text { B } \\
\end{array}$ \\
\hline Intercept-A & 0.24 & & & & & & & & & & & & & \\
\hline CB-A & 0.09 & 0.09 & & & & & & & & & & & & \\
\hline CC-A & 0.05 & 0.05 & 0.13 & & & & & & & & & & & \\
\hline SOUP-A & 0.00 & -0.01 & 0.00 & 0.10 & & & & & & & & & & \\
\hline MILK-A & -0.05 & -0.01 & -0.03 & -0.01 & 0.10 & & & & & & & & & \\
\hline FDE-A & 0.22 & 0.15 & 0.11 & 0.00 & -0.08 & 0.52 & & & & & & & & \\
\hline PT-A & -0.01 & -0.01 & -0.01 & 0.00 & 0.01 & -0.04 & 0.12 & & & & & & & \\
\hline Intercept-B & -0.09 & -0.05 & -0.03 & 0.00 & 0.03 & -0.14 & 0.01 & 0.17 & & & & & & \\
\hline CB-B & -0.05 & -0.03 & -0.02 & -0.01 & 0.02 & -0.09 & 0.01 & 0.05 & 0.07 & & & & & \\
\hline CC-B & -0.07 & -0.04 & -0.04 & -0.01 & 0.03 & -0.15 & 0.02 & 0.04 & 0.05 & 0.15 & & & & \\
\hline SOUP-B & 0.23 & 0.13 & 0.11 & 0.02 & -0.09 & 0.41 & -0.03 & -0.14 & -0.10 & -0.14 & 0.53 & & & \\
\hline MILK-B & 0.14 & 0.08 & 0.07 & 0.01 & -0.05 & 0.25 & -0.02 & -0.09 & -0.04 & -0.09 & 0.26 & 0.23 & & \\
\hline FDE-B & -0.08 & -0.05 & -0.07 & -0.01 & 0.05 & -0.17 & 0.03 & 0.04 & 0.05 & 0.06 & -0.17 & -0.11 & 0.21 & \\
\hline PT-B & 0.02 & 0.01 & 0.01 & 0.01 & -0.02 & 0.04 & 0.00 & -0.02 & -0.01 & -0.01 & 0.06 & 0.03 & -0.03 & 0.11 \\
\hline
\end{tabular}

Note: The numbers in bold are significant at $95 \%$ confidence level.

A-store A

B-Store B

CB-Carbonated Beverage

CC-Cold Cereals

Soup

Milk

FDE-Frozen Dinner Entrée

PT-Paper Towel 


\section{NTERNATI ONAL CHOICE MODELLI NG CONFERENCE}

HOME

АвоUт

LOG IN

ACCOUNT

SEARCH

CURRENT CONFERENCES

ARCHIVE

ANNOUNCEMENTS

JOCM

Home > International Choice Modelling Conference > International Choice Modelling Conference 2013

\section{International Choice Modelling Conference 2013}

The Sebel Pier One Sydney

3 July 2013 - 5 July 2013

The International Choice Modelling Conference brings together leading researchers and practitioners from across different areas of study, with presentations looking both at state of the art methodology as well as innovative real world applications of choice models.

Following on from the success of the second Conference held in Leeds 2011, the third International Choice Modelling Conference will be

organised jointly by the Centre for the Study of Choice (CenSoC) at the University of Technology Sydney (UTS) and the Institute of Transport

and Logistics Studies (ITLS) at the University of Sydney.

The 2013 Conference is being held at The Sebel Pier One Sydney from July 3 - 52013.

Feedback from ICMC 2013

\section{Conference I nformation}

$$
\begin{aligned}
& \text { 》 Overview } \\
& \text { 》 Track Policies } \\
& \text { » Programme } \\
& \text { » Presentations and Authors } \\
& \text { 》 Registration } \\
& \text { »Travel/Accommodation } \\
& \gg \text { Organisers/Sponsors } \\
& \gg \text { Timeline }
\end{aligned}
$$

USER

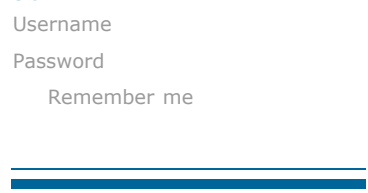

CONFERENCE CONTENT Search

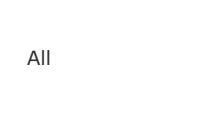

Conference Information

" Overview

Track Policies

" Programme

Presentations

Reqistration

Travel/Accommodation

" $\underline{\text { Organiserseline }}$

Browse

By Conference

- By Author

By Title

\begin{tabular}{l} 
OPEN CONFERENCE SYSTEMS \\
\hline
\end{tabular}




\section{NTERNATI ONAL CHOI CE MODELLI NG CONFERENCE}

HOME

LOG IN

ACCOUNT

SEARCH

CURRENT CONFERENCES

ARCHIVE

ANNOUNCEMENTS

JOCM

Home > International Choice Modelling Conference > International Choice Modelling Conference $2013>$ Track Policies

Track Policies

\section{General Papers}

$\checkmark$ Open Submissions

Special sessions

$\checkmark$ Open Submissions

$\checkmark$ Peer Reviewed

\ Peer Reviewed
USER

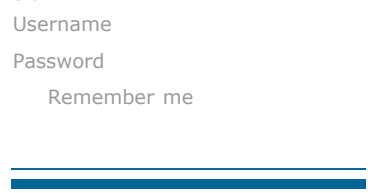

$\square^{\mathrm{R}}$

CONFERENCE CONTENT

Search

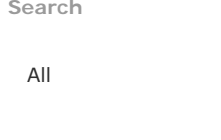

Search

Conference Information

" Overview

Track Policies

" Programme

Presentations

" Reqistration

Oravel/Accommodation

Organisers/Sponsors

Browse

By Conference

By Author

- By Title

\begin{tabular}{l} 
FONT SIZE \\
OPEN CONFERENCE SYSTEMS \\
\hline
\end{tabular}




\section{NTERNATI ONAL CHOI CE MODELLI NG CONFERENCE}

HOME

ABOUT

LOG IN

ACCOUNT

SEARCH

CURRENT CONFERENCES

ARCHIVE

ANNOUNCEMENTS

Home > International Choice Modelling Conference > International Choice Modelling Conference $2013>$ Presentations and Authors

\section{Presentations and Authors}

\section{Title \\ Search

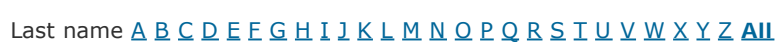 \\ Track: All Tracks}

\section{General Papers}

Finding your way out: Utility maximization and regret minimization in the presence of opt out alternatives Stephane Hess, Matthew Beck, Caspar Chorus

Analysis of Drivers' Route Choice Behavior Considering Probabilistic Choice Set Gang Xu, Tomio Miwa, Takayuki Morikawa

The influences of individuals in joint decisions: recreation in the Alps in Italy Mara Thiene, Cam Rungie, Riccardo Scarpa

Effects of en-route choices on utility-based route choice modeling: an empirical analysis Dawei Li, Tomio Miwa, Takayuki Morikawa

The $2 \mathrm{~N}$-ary choice tree model for preferential choice with $\mathrm{N}$-alternative multi-attribute choice options Adele Diederich, Lena Wollschlaeger

A strategic perspective on work mode choice behaviour: The concept of commuting plans J offre Swait, Michiel Bliemer

Probabilistic Choice (Models) as a Result of Balancing Multiple Goals J offre Swait, Anthony Marley

Structural Choice Modelling of Discrete Choice Experiments

$$
\text { Len Coote, Cam Rungie, J ordan Louviere }
$$

Evaluating Decision Makers' Preferences via Lexicographic Semiorders Clintin Davis-Stober, Nicholas Brown, Daniel Cavagnaro

A Single Latent Dimension Explains Accepting and Rejecting Guy Hawkins, Scott D. Brown, Andrew Heathcote

Linking Discrete Choice to Continuous Demand in a Computable General Equilibrium Model - With Applications to Economic Policy Evaluation

Truong Phuoc Truong, David Alan Hensher

Stated attribute cut-offs in choice experiments: do they affect the variance of choices? Riccarda Moser, Roberta Raffaelli

Latent Class Choice Models with Feedback through Consumer Surplus Vij Akshay, Joan Walker

Overcoming Challenges and Improvements in Best-Worst Elicitation: Determining What Matters to Japanese Wheat Millers

Paul F. Burke, Jordan J. Louviere, Edward Wei, T. Gordon MacAulay, Ken Quail, Richard T. Carson Sequential attribute presentation effects in stated choice experiments: A study in the context of holiday destination choice

Twan Huybers, Harmen Oppewal, Geoffrey I. Crouch

Hybrid Choice Models for Decision Uncertainty: Implicitly or explicitly uncertain?

Thijs Dekker, Stephane Hess, Roy Brouwer, Marjan Hofkes

A latent variable approach to dealing with missing or inaccurately measured variables: the case of income Stephane Hess, Nobuhiro Sanko, Jeff Dumont, Andrew Daly

Stated innovation diffusion model from stated preference data: The Case of Photo-Voltaic (PV) Solar Cells for Household Electricity Generation

Towhidul Islam

Attitudes towards and preferences for end-of-life care: results from discrete choice experiments in Australia
JOCM

USER

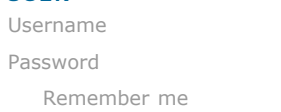

$\square$ Ren

Log In

CONFERENCE CONTENT

Search

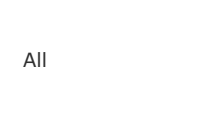

ABSTRACT PAPER

Conference Informatio

》 Overview

Track Policies

Programme

Presentations

Registration

Travel/Accommodatio

Organisers/Sponso

ABSTRACT PAPER

ABSTRACT PAPER PRESENTATION

Browse

By Conference

By Author

By Title

ABSTRACT

ABSTRACT

ABSTRACT PAPER

FONT SIZ

A A $\mathrm{A}$

OPEN CONFERENCE SYSTEMS

ABSTRACT PRESENTATION

ABSTRACT PAPER PRESENTATION

ABSTRACT PDF ()

ABSTRACT PDF ()

ABSTRACT PDF ()

ABSTRACT PDF (

ABSTRACT PDF () PDF

ABSTRACT PDF () PDF

ABSTRACT PDF () PDF

ABSTRACT XML () 
Yuanping Ying, Linda Court Salisbury, Fred M. Feinberg

A New Baseline Model for Estimating Willingness to Pay from Discrete Choice Models Mikolaj Czajkowski, Richard T. Carson

Random Regret Minimization: Overview of empirical performance and policy implicatons Caspar Chorus, Sander van Cranenburgh

Cognitive burden in discrete choice experiments: the case of preferences for end-of-life care in Singapore Marcel Bilger, Chetna Malhotra, Eric Finkelstein, Assad Farooqui, Terry Nicholas Flynn

Valuing Protection of the Belum-Temengor Forest Complex to the Malaysian Public

Richard T. Carson, J. R. DeShazo, Kurt Schwabe, J effrey R Vincent

Learning how to choose - effects of instruction choice sets on stated choices Juergen Meyerhoff, Klaus Glenk

Consumer heterogeneity in the willingness to pay for local organic food Johanna Hasselbach, Jutta Roosen

Bounding WTP distributions to reflect the 'actual' consideration set Danny Campbell, David A Hensher, Riccardo Scarpa

An investigation of individual preferences: stability over time and consistency across incentives Emmanouil Mentzakis, Jingjing Zhang

A hybrid mode choice model to account for the dynamic effect of inertia over time Elisabetta Cherchi, Maria Borjesson, Michel Bierlaire

Time, product features and the role of information framing in choices of more efficient appliances J orge Arana, Jordan Louvier, Darla Hatton MacDonald, John Rose

Combining multiple DCEs from the same respondents and different product categories: A structural choice modeling approach.

$$
\text { Jasha Henry Bowe }
$$

Check it out! A Monte Carlo analysis of the performance of selection criteria and tests for Choice Experiments models

Elisabetta Strazzera, Davide Contu, Silvia Ferrini

Is Attribute Non-attendance Affected by the Dimensionality of Stated Choice Experiments? Priska J ohanna Weller, Malte Oehlmann, Jürgen Meyerhoff

Estimating Mixed Logit Models with Large Choice Sets Roger H. von Haefen

Choice Models in Communication Studies: the Framing of Communication on Carbon Capture and Storage. Kevin P.F. Broecks, Sander van Egmond, Frank J. van Rijnsoever, Marko P. Hekkert, Marlies Verlindevan den Berg

The incorporation of subjective risks into choice experiments to test the scenario adjustment Simone Cerroni, W. Douglass Shaw, Sandra Notaro, Roberta Raffaelli

Choice Models in Communication Studies: the Communication of Arguments on Carbon Capture and Storage.

Kevin P.F. Broecks, Sander van Egmond, Frank J. van Rijnsoever, Marko P. Hekkert, Marlies Verlindevan den Berg

A joint mode/time-of-day choice model using combined revealed preference and stated choice data Pedro Lizana, Juan de Dios Ortuzar, Julian Arellana, Luis Ignacio Rizzi

Testing Consumer Decision Strategies in Comparative and Non-Comparative Choice Tasks: A Structural Choice Modelling Formulation of the Evaluability Thesis Ann Wallin, Len Coote

Analysing the Merit of Latent Variables over Traditional Objective Attributes for Traveller Mode Choice Using RPL Model

A.H.M. Mehbub Anwar, Kiet Tieu, Peter Gibson, Khin Than Win, Matthew Berryman

An Application of Structural Choice Modelling to the Study of Choice Set Size

Thomas Magor, Len Coote

An investigation into the effect of competitive context on brand price elasticities Steven Dunn, Svetlana Bogomolova, John Dawes

Comparing forced and unforced choices in a choice experiment: the role of reference dependent preferences Anthony Scott, Julia Witt

Introducing Factorial Structures to Discrete Choice Experiments

George Chryssochoidis

ABSTRACT PDF PAPER

ABSTRACT UNTITLED ()

$\underline{\text { ABSTRACT }} \underline{\text { DOC }} \underline{\text { PDF }}$

ABSTRACT PDF $(1$

ABSTRACT PDF () PDF

ABSTRACT

ABSTRACT PAPER PRESENTATION

ABSTRACT PDF () PDF

ABSTRACT PDF () PDF

ABSTRACT XML

ABSTRACT

ABSTRACT PDF ()

ABSTRACT PDF ()

ABSTRACT PAPER PRESENTATION

ABSTRACT PDF ()

ABSTRACT

ABSTRACT PDF ()

ABSTRACT PDF () PDF

ABSTRACT PDF

ABSTRACT PDF ()

ABSTRACT PDF ()

ABSTRACT PDF ()

ABSTRACT PDF (

ABSTRACT PAPER PRESENTATION 
Alireza Zolfaghari, Dr Aruna Sivakumar, Prof J ohn Polak

What Is the Tolerable Walking Distance to School? Application of a Discrete Hazard-based Model and a Random Utility Method

Alireza Ermagun, Amir Samimi, Taha Hossein Rashidi

Introducing relations between activities and goods consumption in microeconomic time use models Sergio R. Jara-Diaz

How do travellers value their travel time? A study-case for the Madrid-Barcelona corridor

Raquel Espino, Concepción Román, Juan Carlos Martín, Elisabetta Cherchi, Juan de Dios Ortúzar, Luis I gnacio Rizzi, Rosa Marina González, Francisco Javier Amador

Evidence-based environmental attributes in choice experiments

Marit Ellen Kragt

REVIEW OF THE APPLICATION OF LATENT VARIABLES TO THE ATTRIBUTES IN DISCRETE CHOICE MODELS

Cam M Rungie

Dynamic Menu Choice - A new tool for an old problem

Paul Markowitz, Jason Lee

Is "choosing the best" the opposite of "choosing the worst"? - utility and emotion in best and worst choices.

J ordan Louviere, Carsten Rasch, Thorsten Teichert

The use of status quo and opt out options in choice experiments. Implications of researchers dubious use of the 'neither' option

Line Bjørnskov Pedersen, Dorte Gyrd-Hansen

What drives active transportation choices among the aging population? Comparing a Bayesian belief network and mixed logit modeling approach

Astrid Kemperman, Harry Timmermans

A study on bias in logit model estimates caused by self-reported choice sets Sander Van Cranenburgh, Caspar G. Chorus

Discrete continuous choice model to determine participation in contractual biodiversity conservation by pastoralists in northern Australia Julie Ballweg

Using Multivariate Adaptive Regression Splines (MARS) to Find Interactions of Socio-Demographics That Model Individual Differences in Australian Farmers Purchase Behavior Ingo Bentrott

Does familiarity with a choice task increase the use of heuristics? Evidence from a Choice Experiment Mylene Lagarde

Developing a new end-of-life instrument for use in economic evaluation J oanna Coast, Philip Kinghorn, Elisabeth Huynh, Terry Nicholas Flynn

CORRECTING FOR ENDOGENEITY WITHOUT INSTRUMENTS IN DISCRETE CHOICE MODELS: THE MULTIPLE INDICATOR SOLUTION Cristian Angelo Guevara, Daniel Polanco

Does Social Networking Substitute for or Stimulate Teenagers' Travel? Findings from a Latent Class Mode Maria Kamargianni, Amalia Polydoropoulou

A Bayesian Approach to Latent Heterogeneity of Preferences in Travel Mode Choice Models Olvar Bergland, Stefan Flügel

Route-Choice Modeling using GPS-based Travel Surveys Sivaramakrishnan Srinivasan, Nagendra Dhakar

Modeling wine consumers preferences: How different can consumers be?

David Esteban Palma, Juan de Dios Ortúzar, Luis Ignacio Rizzi, Eduardo Agosin, Gerard Casaubon

A Utility Theory for Logit Models with Repeated Choices Eric English

Estimating Conditional Certainty Equivalents using Choice-Experiment Data Juan Marcos Gonzalez, A Brett Hauber, F Reed Johnson

Labelling effects for alcoholic drinks in Australia: Evidence from three experimental designs Doina Olaru, Wade Jarvis

THE USE OF RISK-BASED DISCRETE CHOICE EXPERIMENTS TO ELICIT PREFERENCES FOR DIFFERENT HEALTH STATES

Angela Robinson, Anne Spencer, Peter Moffatt

WTP for the integration between the HSR and air transport at Madrid Barajas airport Juan Carlos Martin, Concepción Román

ABSTRACT PDF ()

ABSTRACT PDF PAPER

ABSTRACT PDF (

ABSTRACT

ABSTRACT UNTITLED () PAPER PRESENTATION

$\underline{\text { ABSTRACT PDF () }} \underline{\text { PDF }}$

ABSTRACT XML () PDF

ABSTRACT PDF () PDF

ABSTRACT PDF ()

ABSTRACT XML () PDF ()

ABSTRACT XML

ABSTRACT PDF (

ABSTRACT PDF ()

ABSTRACT DOC PDF

ABSTRACT PDF () PDF

ABSTRACT PDF ()

ABSTRACT PDF (

ABSTRACT

ABSTRACT PDF (

ABSTRACT PDF (1)

ABSTRACT XML ()

ABSTRACT PDF () PDF

ABSTRACT PDF ()

$\underline{\text { ABSTRACT }} \underline{\mathrm{XML}(1}$ 
Attribute-level non-attendance in a choice experiment investigating preferences for health service innovations

Seda Erdem, Danny Campbell, Arne Risa Hole

Choice consistency and its determinants dan rigby

Inferred vs stated attribute non-attendance in choice experiments: A study of doctors' prescription behaviour

Arne Risa Hole, Julie Riise Kolstad, Dorte Gyrd-Hansen

Acceptance of life-threatening hazards among young tourists: a stated choice experiment igor sarman, stefano scagnolari, rico maggi

The role of altruism in non-market valuation.

Anna Bartczak

Cardinal utility for applied research using situation-specific choice experiments

Daniel Gregg

Estimating QALY values from discrete choice experiments using mixed logit models Yuanyuan Gu, Richard Norman, Rosalie Viney

The sequencing effects of including choice experiments and contingent valuation in the same survey Jill Windle, John Rolfe

Using a latent variable choice model to capture heterogeneous attitudes and preferences toward the landscape externalities of wind power generation Petr Mariel, Jürgen Meyerhoff, Stephane Hess

Providing real economic incentives in Choice Experiments - extending the aim from hypothetical bias mitigation to behavioral benefits in a broader sense

Morten Raun Mørkbak, Søren Bøye Olsen, Sigrid Denver, Danny Campbell

Predictive validity across product categories with similar attributes.

Abou Bakar, Richard Lee, Cam M Rungie

Hypothetical Bias or Model Misspecification?: Evidence from the field

J orge Araña, Simon Fifer, John Rose, Carmelo León

Forecast combination for discrete choice models: predicting FOMC monetary policy decisions Andrey Vasnev, Laurent Pauwels

Efficient Availability Stated Choice Designs J ohn Rose, Jordan Louviere, Michiel Bliemer

The regret of not modelling regret in choice experiments: a Monte Carlo investigation Marco Boeri, Alberto Longo, Riccardo Scarpa

The perceived unreliability of rank-ordered data: an econometric origin and empirications Hong il Yoo

Valuation of small and multiple health risks: A critical analysis of SP data applied to food and water safety Henrik Andersson, Arne Risa Hole, Mikael Svensson

Citizen Preferences for Multifunctional Agriculture in the Watershed Areas of Northern Thailand: A Latent Class Choice Model Chapika Sangkapitux

What If You Had To Eat It? Addressing Incentive Compatibility in a Food Choice Experiment Darla Hatton MacDonald, John Rose, Haidee J Lease, David N Cox

Modelling "on-the-fly" spatial decisions: The case of refuelling Ari Pramono, Harmen Oppewal

Making productive use of the wasted: a behavioural model of activity choice for business travel time and mplications of ICT use for in-travel productivity. Jacek Pawlak

Equilibrium in Transportation Networks: Is it Pure, Mixed, Stochastic or Quantal Response? Vinayak V Dixit, Laurent Denant-Boemont

Modelling the Effects of Driving Range Uncertainty on Electric Vehicle Users' Charging Behaviour Nicolo' Daina, Aruna Sivakumar, John Polak

The influence of design dimensions on stated choices - an example from environmental valuation using a design-of-designs approach

ABSTRACT PDF ()

ABSTRACT PDF ()

ABSTRACT PDF ()

$\underline{\text { ABSTRACT PDF () PDF }}$

ABSTRACT UNTITLED UNTITLED () PDE

$\underline{\text { ABSTRACT }}$

$\underline{\text { ABSTRACT }} \underline{\text { XML () }}$

ABSTRACT PDF () PDF

ABSTRACT UNTITLED () PDF

ABSTRACT PDF () PDF

ABSTRACT PDF (

ABSTRACT PAPER UNTITLED

PRESENTATION

ABSTRACT

ABSTRACT PDF ()

ABSTRACT $\underline{\text { XML () }}$

ABSTRACT PDF () PDE

ABSTRACT PDF ()

ABSTRACT PDF () PDF

ABSTRACT UNTITLED ()

ABSTRACT XML ()

$\underline{\text { ABSTRACT PDF () }}$

ABSTRACT PDF () PDF

ABSTRACT XML ()

ABSTRACT PDF ()

ABSTRACT PDF () PDF 
Modeling car ownership and usage: a dynamic discrete-continuous choice modeling approach Aurélie Glerum, Emma Frejinger, Anders Karlström, Muriel Beser Hugosson, Michel Bierlaire

The Random Subspace Proportional Hazard Model (RSPHM) For Inter-shopping Duration Behzad Karimi, Zahra Pourabdollahi, Abolfazl (Kouros) Mohammadian

The Public's Preference for Green Power in Australia

Chunbo Ma, Michael Burton

Design Choices for Studies of Decision Making Spring Sampson

Effects of consumer trust in the label on choice: an empirical study of organic logos in Italy Raffaele Zanoli

Environmental Value Orientations in Discrete Choice Experiments: A Latent Variables Approach David Hoyos, Petr Mariel, Stephane Hess

A generalized relative utility based choice model with multiple context dependencies J unyi Zhang

Modelling Electric Vehicle Adoption in the UK: Does the experience of using an electric vehicle change stated preference?

Aruna Sivakumar, Nicolo Daina, John Polak, Stephen Skippon, Jenny Stannard

Investigating Differences between Internet and Mail Implementation of a Stated-Preference Study While Controlling for Differences in Sample Frames and Self-Selection Effects Mark Morrison, Darla Hatton MacDonald, Kevin Boyle, John Rose, Roderick Duncan

Hybrid Choice Modelling of Alternative Fuel Vehicles Including Second Order Structural Equations Jose Soto, Victor Cantillo, Julian Arellana

The comparative efficacy of combining latent class and nested logit (LCNL) to simultaneously account for inter-alternative correlation and taste heterogeneity so as to improve toll route choice forecasts. Collins Teye-Ali, Peter Davidson, Rob Culley

Choice-Modeling of Environmental Trade-offs in Subsistence Economies: Lessons from the Brazilian Coast and Rainforests

James Randall Kahn, Alexandre A.F. Rivas, Carlos Eduardo Rezende

A New Spatial Multiple Discrete-Continuous Modeling Approach to Land Use Change Analysis Chandra R Bhat, Subodh Dubey, Rajesh Paleti

The Formulation and Estimation of a Spatial Lag Ordered-Response Model with Non-Normal Kernel Distribution and Non-Normal Individual Mixing Distribution

Chandra R Bhat, Sebastian Astroza, Rajesh Paleti

Robot Choices

Mary-Anne Williams

Understanding the role of patient perceptions of treatment outcomes in the face of limited clinical evidence Mirja Elisabeth Klojgaard, Stephane Hess

Antecedent Volition \& Process Representation in Models of Choice Behaviour J offre Swait

The best of both worlds: integrating psychological and econometric theories of choice Scott Brown

ABSTRACT PDF ()

ABSTRACT

ABSTRACT PAPER PRESENTATION

ABSTRACT UNTITLED () PDF

ABSTRACT PDF ()

ABSTRACT XML ()

ABSTRACT XML ()

ABSTRACT

ABSTRACT DOC

ABSTRACT DOCX

ABSTRACT XML ()

ABSTRACT UNTITLED ()

ABSTRACT XML ()

ABSTRACT PDF

ABSTRACT PDF

ABSTRACT PDF

ABSTRACT PDF

$$
\text { David Brownstone }
$$

ABSTRACT PDF 
Vic Adamowicz

Estimating Demand for High Fuel Economy Vehicles

David S Bunch, David Brownstone

Impact of household time constraints on person travel demand: the notion of family priority time in activity based models

Goran Vuk, John L Bowman, Stephane Hess, Andrew Daly

\section{ABSTRACT PRESENTATION}

ABSTRACT PAPER 